\title{
L081 MODELS FOR THE ACTIVE SITES IN THE MANGANESE CATALASE, OXYGEN EVOLVING COMPLEX AND VANADIUM BROMOPER-
}

OXIDASE. V.L. Pecoraro, X. Li, J.A. Bonadies, M.S. Lah, E. Larson and S. Saadeh, Department of Chemistry, University of Michigan, Ann Arbor, MI 48109-1055, USA.

Schiff Base and $\alpha$-hydroxy acid complexes of manganese will be presented as models for the spectroscopic and reactivity behavior of oxygen metabolising manganese enzymes. Specific emphasis will be placed on evaluating the active site cluster nuclearity and the role of calcium ion in the photosynthetic oxygen evolving enzyme. Vanadium (IV) and (V)complexes of alkoxy Schiff base ligands will be examined as models for the vanadium bromoperoxidase active site. The solution chemistry of Vanadium monomers and dimers will be presented.

\section{L082 SOLVENT-DEPENDENCE OF THE REACTION OF MANGANESE PORPHYRINS WITH}

SUPEROXIDE ION. A. Gaudemer. M. Perree-Fauvet. J.J. Girerd, J. Bonvoisin, P Boucly, UA CNRS, ICM0. Universite Paris-Sud, 91405-Orsay (France).

The reaction of superoxide ion with CIMnTPP and MnTPP (py) has been studied by linear voltammetry, visible spectroscopy, EPR and NMR. Depending on the concentration of the superoxide and on the solvent two anionic complexes are generated. (MnTPPO $\left.{ }_{2}\right)^{-}$and a dimer, which, on the basis of its EPR spectrum is formulated as a di- $\mu$-oxo $\mathrm{Mn}(\mathrm{III})-\mathrm{Mn}$ (IV) porphyrin. The mixed-valence dimer is easily obtained in toluene while $\left(\mathrm{MnTPPO}_{2}\right)^{-}$is preferably formed in polar solvents. $\left(\mathrm{MnTPPO}_{2}\right)^{-}$is FPR silent but exhihits a ${ }^{1} \mathrm{H}$ NMR spectrum characteristic of a high spin Mn(III). Electrochemistry gives evidence that. in DMSO $0_{2}^{-}$and Mn(IITPP do nat strongly bind.

L083 THE CHLORINATING ACTIVITY OF HUMAN MYELOPEROXIDASE DIMER AND MONOMER: HIGH INITIAL VELOCITY AT NEUTRAL OH AND ACTIVATION BY ELECTRON DONORS.

K.W.M.Zuurbier, A.R.J.Bakkenist, J.van den Berg, R.Wever and A.O.Muljsers, E.C.Slater Institute, University of Amsterdam, Meibergdreef 15, 1105 AZ Amsterdam, The Netherlands.

The activity of myeloperoxidase (isolated as a dimer) in the chlor ination of monochlorodimedone at $\mathrm{pH} 7$ was investigated by means of rapid-scan stopped-flow spectrometry. Initial turnover of $320 \mathrm{~s}^{-1}$ per heme, measured within $100 \mathrm{~ms}$, rapidly declined to $25 \mathrm{~s}^{-1}$ after 1 s. Transient spectra showed this to be due to formation of inactive Compound 11 . In the presence of the reductant 5-aminosalicylic acid, however, a high residual activity after $5 \mathrm{~s}$ of $150 \mathrm{~s}^{-1}$ remained. The 5 -aminosalicylic acid conver ted Compound II back to native enzyme with $k=3.10^{5}$ $M^{-1} \cdot s^{-1}$, making it a useful tool in the study of myeloperoxidase activity. From the disulfideconnexted dimer myeloperoxidase a stable monomer could be prepared by reductive carboxymethylation. It showed transient - and steady-state kinetics similar to those of the dimer enzyme. 